Doi: HTTPS://DOI.ORG/10.23910/IJBSM/2017.8.1.1774

\title{
Effect of Sowing Dates and Stage of Pinching on Growth, Yield and Quality of Fenugreek (Trigonella foenum-graecum L.)
}

\author{
P. T. Sowmya, I. S. Naruka, R. P. S. Shaktawat* and S. S. Kushwah
}

Dept. of Plantation, Spices, Medicinal and Aromatic Crops RVSKVV College of Horticulture, Mandsaur, M.P. (458 001), India

\author{
Corresponding Author \\ R. P. S. Shaktawat \\ e-mail: rpssbkn@yahoo.co.in
}

\author{
Article History \\ Manuscript No. AR1774 \\ Received in $11^{\text {th }}$ Jan, 2017 \\ Received in revised form $5^{\text {th }}$ Feb, 2017 \\ Accepted in final form $7^{\text {th }}$ Feb, 2017
}

\begin{abstract}
An experiment entitled effect of sowing dates and stage of pinching on growth, yield and quality of fenugreek was carried out during September 2015 to March 2016 at RVSKVV College of Horticulture, Mandsaur, M.P., India, with 12 treatment combinations, comprising four dates of sowing $25^{\text {th }}$ September, $10^{\text {th }}$ October, $25^{\text {th }}$ October and $9^{\text {th }}$ November with three stages of pinching i.e., No pinching, Pinching at 25 Days after sowing (DAS), Pinching 35 DAS. These treatments were replicated thrice in split spot design and analyzed. Treatment with $10^{\text {th }}$ October sowing recorded maximum plant height, number of branches, fresh weight, dry weight, number of pods plant ${ }^{-1}$, pod length, weight of pod, number of seeds pod ${ }^{-1}$, weight of seeds pod ${ }^{-1}$, thousand seed weight, seed yield, straw yield, biological yield, harvest index, chlorophyll content, germination $\%$, seedling vigour index, protein\%, galactomannon content. While, $25^{\text {th }}$ September sown crop took maximum days for $50 \%$ flowering and for maturity. Between pinching stages studied, Pinching at 35 DAS found to be superior in respect of number of branches plant ${ }^{-1}$, fresh and dry weight of plant $(\mathrm{g})$ at harvest, number of pods plant ${ }^{-1}$, length of pod $(\mathrm{cm})$, weight of pod $(\mathrm{mg})$, number of seeds $\operatorname{pod}^{-1}$, weight of seeds $\operatorname{pod}^{-1}(\mathrm{mg})$, thousand seed weight $(\mathrm{g})$, seed yield (q ha-1), straw yield ( $\mathrm{q}$ ha $\left.{ }^{-1}\right)$, biological yield $(\mathrm{q}$ $\mathrm{ha}^{-1}$ ), harvest index (\%), chlorophyll content in leaves at 75 DAS (SPAD), germination percentage of seeds, seedling vigour index, protein (\%) and galactomannon in comparison to other pinching stages.
\end{abstract}

Keywords: Fenugreek, growth, pinching, quality, sowing dates, yield

\section{Introduction}

Fenugreek (Trigonella foenum-graecum L.), commonly called as 'Greek hay' and also called as 'methi' in Hindi, belonging to the family Fabaceae. The plant is erect or spreading, growing up to a height of $30-90 \mathrm{~cm}$. Fenugreek seeds are rich in protein (6.3\%), fat (9.5\%), carbohydrates (42.3\%) and vitamin A $(1040 \mathrm{~W})$. Besides, it contains gum (22.06\%), trigonellin $(0.13-0.35 \%)$, diosgenin $(1.0 \mathrm{~g})$. Among the various cultural practices, proper time of sowing is a prerequisite (Nandre et al., 2011), climatic factors such as temperature, duration of bright sunshine and relative humidity differs with sowing time of the crop, which ultimately influence the growth and yield of the crop in fenugreek. Apical bud pinching helps in altering the source sink relationship by curbing the vegetative growth and hastening reproductive phase of the plant. It also helps in production of side shoots or branches thus resulting in increased photosynthetic activity and accumulation of more photo-synthates ultimately resulting in increased seed size and yield (Lakshmi et al., 2015). Several attempts have been made in cultivation of fenugreek in the past to increase the productivity and quality, out of which optimum date of sowing and pinching plays may play an important role to boost the productivity. Keeping all these in mind, an experiment entitled effect of sowing dates and stage of pinching on growth, yield and quality of fenugreek was conducted to increase growth, yield and quality in fenugreek.

\section{Materials and Methods}

The present investigation was conducted during September 2015-March 2016 at the Research Farm, RVSKVV College of Horticulture, Mandsaur, M.P., India. The soil of the experimental field was light black loamy in texture with low nitrogen (243.2 kg ha-1), medium phosphorus (19.75 kg ha-1), high potassium (448.0 $\left.\mathrm{kg} \mathrm{ha}^{-1}\right)$ and neutral in reaction $(\mathrm{pH}$ 6.5). The experiment consisted of 4 dates of sowing i.e., $25^{\text {th }}$ September, $10^{\text {th }}$ October, $25^{\text {th }}$ October and 9 th November and 3 stages of pinching i.e., No pinching, Pinching at 25 DAS, Pinching at 35 DAS. These treatments were evaluated under split plot design with three replications. Seeds were sown in the field with the spacing of $30 \times 10 \mathrm{~cm}^{2}$ and watered immediately. Recommended cultural practices were followed during the entire crop period. Data was recorded for various 
growth, yield and quality parameters and statistically analyzed using the method of analysis of variance as described by Pansey and Sukhatme (1985).

\section{Results and Discussion}

\subsection{Effect of sowing dates}

The plant height was significantly influenced by different sowing dates. At harvest, seeds sown on $10^{\text {th }}$ October were found tallest $(69.35 \mathrm{~cm})$ as compared to other sowing dates. The increased plant height may be due to the mean temperature requirement of fenugreek which closely coincided with the prevailing temperature in the month of October. Similar results were also reported by Nandre et al. (2011). Significantly more number of branches plant ${ }^{-1}$ (16.53) was noticed in the crop sown on $10^{\text {th }}$ October, whereas minimum branches plant ${ }^{-1}(11.05)$ were noticed in $9^{\text {th }}$ November sown crop (Table 1 ). This might be attributed to the optimum temperature and relative humidity prevailing during crop period which might have given the plants an adequate opportunity for photosynthesis, so the branch bearing capacity increased. The results are in agreement with Ayub et al. (2008) in fennel. Days taken for harvesting were found to be significantly influenced by different sowing

Table 1: Effect of sowing dates and stage of pinching on growth attributes of fenugreek

\begin{tabular}{lccccc}
\hline Treatments & PH & BP & DF & FWP & DWP \\
\hline Sowing dates & & & & & \\
\hline $25^{\text {th }}$ September & 55.89 & 13.16 & 53.33 & 20.76 & 4.20 \\
$10^{\text {th }}$ October & 69.35 & 16.53 & 51.33 & 29.88 & 5.47 \\
$25^{\text {th }}$ October & 65.69 & 14.16 & 49.33 & 21.91 & 4.48 \\
$9^{\text {th }}$ November & 65.09 & 11.05 & 46.00 & 15.17 & 3.04 \\
SEm \pm & 0.458 & 0.403 & 0.440 & 0.813 & 0.198 \\
CD $(p=0.05)$ & 1.586 & 1.395 & 1.525 & 2.815 & 0.687 \\
Stage of pinching & & & & & \\
No pinching & 65.10 & 12.38 & 46.75 & 18.76 & 3.19 \\
Pinching at 25 DAS & 63.17 & 13.52 & 53.25 & 21.65 & 4.77 \\
Pinching at 35 DAS & 63.73 & 15.28 & 50.00 & 25.38 & 4.94 \\
SEm \pm & 0.504 & 0.296 & 0.652 & 0.836 & 0.224 \\
CD $(p=0.05)$ & 1.512 & 0.889 & 1.957 & 2.507 & 0.672 \\
\hline
\end{tabular}

PH: Plant height (cm); BP: Branches plant ${ }^{-1}$; DF: Days to $50 \%$ flowering; FWP: Fresh weight plant ${ }^{-1}(\mathrm{~g})$; DWP: Dry weight plant $^{-1}(\mathrm{~g})$

dates. In the present study, sowing on $9^{\text {th }}$ November recorded minimum days for maturity ( 124 days). These results can be attributed to the prevalence of low temperature during the month of November which has accelerated early flowering, early maturity and harvest. The fresh weight and dry weight of the plant were significantly influenced by different sowing dates. Significantly maximum fresh weight $(29.88 \mathrm{~g})$ and dry weight of plant $(5.47 \mathrm{~g})$ were noticed in the crop sown on 10th October, whereas minimum fresh weight $(15.17 \mathrm{~g})$ and dry weight of plant $(3.04 \mathrm{~g})$ were noticed in $9^{\text {th }}$ November sown crop. Improvement in overall growth i.e., plant height and number of branches plant ${ }^{-1}$ with the early date of sowing coupled with increased net photosynthesis towards reproduction structure, on the other, might have increased the yield attributes significantly. This may be due to the fact that delay sowing could not have sufficient time for vegetative growth, result in poor plant canopy which adversely affected the fresh and dry weight of the plant at 45, 75 DAS and at harvest. Similar results were also observed by Krishnaveni et al. (2014) in fenugreek.

In the present study it was observed that different dates of sowing had significant effect on the pod and seed characters. The maximum number of pods plant ${ }^{-1}$ (75.94), pod length $(11.72 \mathrm{~cm})$ and fresh weight of pod $(661.55 \mathrm{mg})$ were noticed under the crop sown on $10^{\text {th }}$ October. Similarly, maximum number of seeds per pod (16.88), weight of seeds per pod (435.55 $\mathrm{mg}$ ) and thousand seed weight (20.20 g) were registered in $10^{\text {th }}$ October sown crop, whereas minimum values for these pod and seed characters were noticed in 9th November sown crop. Seed yield was also significantly maximum in $10^{\text {th }}$ October sown crop $\left(18.55 \mathrm{q} \mathrm{ha}^{-1}\right) .10^{\text {th }}$ October sown crop also recorded maximum straw yield $\left(44.48 \mathrm{q} \mathrm{ha}^{-1}\right)$ biological yield ( $\left.63.03 \mathrm{q} \mathrm{ha}^{-1}\right)$ and harvest index (29.31\%) (Table 2). This might be due to better vegetative growth in terms of more number of branches per plant, more number of pods plant ${ }^{-1}$ and seeds pod ${ }^{-1}$ due to better photosynthetic efficiency and translocation of photosynthates from source to sink. Further, maximum seed yield resulted in maximizing the harvest index. The maximum seed weight was because of better reproductive growth and seed filling period which significantly increased the harvest index. Results are in agreement with that of Ayub et al. (2008), and Selim et al. (2013).

Further, chlorophyll content in leaves varied significantly with different dates of sowing. At 75 DAS, maximum chlorophyll (59.43 SPAD value) was registered in $10^{\text {th }}$ October sown crop, whereas $25^{\text {th }}$ September sown crop recorded minimum chlorophyll (54.79 SPAD value). The protein content in seeds was also influenced due to sowing dates. The crop sown in $10^{\text {th }}$ October recorded maximum protein (18.63\%), minimum in the crop sown on $9^{\text {th }}$ November. This might be due to better plant growth due to favourable climatic conditions prevailing during the period and more photosynthetic activity has resulted in better seed filling resulting in the quality seeds in terms of higher protein content. Date of sowing had non-significant effect on galactomannon content of seed, maximum galactomannon of seeds was observed in 10th October sown crop (26.14\%), whereas minimum was in 25 th September sown crop (25.14\%). The maximum germination and seedling vigour of seeds were observed in $10^{\text {th }}$ October 


\begin{tabular}{|c|c|c|c|c|c|c|c|}
\hline Treatments & $\begin{array}{l}\text { Pods } \\
\text { plant }^{-1}\end{array}$ & $\begin{array}{l}\text { pod length } \\
(\mathrm{cm})\end{array}$ & $\begin{array}{l}\text { weight of } \\
\text { pod }(\mathrm{mg})\end{array}$ & Seeds pod ${ }^{-1}$ & $\begin{array}{l}\text { weight of seeds } \\
\text { pod }^{-1}(\mathrm{mg})\end{array}$ & $\begin{array}{l}1000 \text { seed } \\
\text { weight }(\mathrm{g})\end{array}$ & $\begin{array}{l}\text { Days taken for } \\
\text { maturity }\end{array}$ \\
\hline \multicolumn{8}{|l|}{ Sowing dates } \\
\hline $25^{\text {th }}$ September & 53.6 & 10.63 & 345.55 & 15.48 & 296.66 & 19.14 & 139.44 \\
\hline $10^{\text {th }}$ October & 75.9 & 11.72 & 661.55 & 16.88 & 435.55 & 20.20 & 134.00 \\
\hline $25^{\text {th }}$ October & 56.7 & 10.92 & 640.11 & 15.77 & 371.11 & 19.62 & 130.00 \\
\hline $9^{\text {th }}$ November & 37.4 & 10.28 & 256.66 & 15.46 & 175.55 & 16.82 & 124.00 \\
\hline SEm \pm & 1.23 & 0.176 & 9.019 & 0.200 & 8.917 & 0.128 & 0.266 \\
\hline$C D(p=0.05)$ & 4.28 & 0.611 & 31.212 & 0.693 & 30.859 & 0.443 & 0.921 \\
\hline \multicolumn{8}{|l|}{ Stage of pinching } \\
\hline No pinching & 52.1 & 10.51 & 414.58 & 14.95 & 293.33 & 18.24 & 130.75 \\
\hline Pinching at 25 DAS & 57.1 & 10.92 & 485.66 & 16.23 & 324.16 & 19.07 & 133.00 \\
\hline Pinching at 35 DAS & 58.5 & 11.24 & 527.66 & 16.52 & 341.66 & 19.52 & 131.83 \\
\hline SEm \pm & 1.43 & 0.185 & 11.708 & 0.150 & 12.643 & 0.111 & 0.560 \\
\hline $\mathrm{CD}(p=0.05)$ & 4.29 & 0.555 & 35.103 & 0.451 & 37.906 & 0.335 & 1.679 \\
\hline
\end{tabular}

sown crop (97.33\% and 2334.33$)$, whereas minimum was in 9th November sown crop $(73.66 \%$ and 1660.72$)$. The temperature prevailed during 10th October maintained optimum relative humidity which was more congenial for better germination, thus enhanced the seed germination and vigour. Similar results were also reported by Castillo et al. (1994) in pea.

\subsection{Effect of stage of pinching}

In the present study it was observed that plant height was maximum in No pinching i.e., $65.10 \mathrm{~cm}$, whereas minimum in Pinching at 25 DAS i.e., $63.17 \mathrm{~cm}$, while the number of branches plant $^{-1}$ were maximum in Pinching at 35 DAS i.e., 15.28. Decrease in plant height and increase in number of branches with pinching could be ascribed to pinching of apical bud which curbs the vertical growth of plant resulting in translocation of photosynthates to leaf axils thus, encouraging auxillary branches. Activation of lateral dormant buds by arresting the terminal growth through pinching of apical bud would have facilitated the significant increase in number of branches plant ${ }^{-1}$. The results are in agreement with Sajjan (2002) in okra, Baloch and Zubair (2010) in chick pea and Vasudevan et al. (2008) and Krishnaveni et al. (2014) in fenugreek. Maximum Fresh weight $(25.38 \mathrm{~g}$ ) and dry weight $(4.94 \mathrm{~g})$ were recorded in plants pinched at 35 DAS. While non-pinched plants recorded minimum fresh weight (18.76 $\mathrm{g})$ and dry weight $(3.19 \mathrm{~g})$.The results are in agreement with Krishnaveni et al. (2014). Among the pinching treatments, Pinching at 25 DAS recorded maximum days for maturity (133 days) while non-pinched plants recorded minimum days for maturity (130.75 days). The earliness in non-pinched plants and advancement in number of days for maturity in pinched plants may be related to alter in source-sink relationship and because of more production of secondary branches there by advancing the reproductive phase. The results are in agreement with Vasudevan et al. (2008); Krishnaveni et al. (2014) in fenugreek.

Pinching registered significant difference for various yield parameters. The number of pods plant ${ }^{-1}(58.54)$, pod length $(11.24 \mathrm{~cm})$, fresh weight of pod $(527.66 \mathrm{mg})$, number of seeds $\operatorname{pod}^{-1}(16.52)$, weight of seeds pod ${ }^{-1}(341.66 \mathrm{mg})$ and 1000 seed weight $(19.52 \mathrm{~g})$ were maximum in the plants pinched at 35 DAS (P3), while No Pinching recorded minimum number of pods plant ${ }^{-1}(52.15)$, pod length $(10.51 \mathrm{~cm})$, fresh weight of pod ( $414.58 \mathrm{mg}$ ), number of seeds $\operatorname{pod}^{-1}(14.95)$, weight of seeds pod ${ }^{-1}(293.33 \mathrm{mg}$ ) and 1000 seed weight (18.24 g) (Table 3). These results have attributed mainly because of maximum number of branches which in turn has resulted in maximum number of pods plant ${ }^{-1}$, pod length, fresh weight of pod and 1000 seed weight in Pinching at 35 DAS as compared to no Pinching. Beneficial effect noticed with pinching perhaps could be related to effective synthesis and translocation of photosynthates from source to sink which is evident with higher seed weight. The results are in line with Vasudevan et al. (2008), Krishnaveni et al. (2014) in fenugreek and Baloch and Zubair (2010) in chick pea. Seed yield ha ${ }^{-1}$, straw yield and biological yield also differed significantly due to pinching. The significant maximum seed yield (17.08 q ha-1), straw yield (44.16 $17.08 \mathrm{q} \mathrm{ha}^{-1}$ ) and biological yield (61.25 $17.08 \mathrm{q}$ $\mathrm{ha}^{-1}$ ) was obtained in Pinched at 35 DAS while, minimum was noticed in the plants with no pinching (13.38 $17.08 \mathrm{q} \mathrm{ha}^{-1}$ ) of seed yield and (42.60 q and 55.99 q) of straw and biological yield and pinching at 25 DAS (14.73 $17.08 \mathrm{q} \mathrm{ha}^{-1}, 43.4017 .08$ q ha ${ }^{-1}$ and $58.1317 .08 \mathrm{q} \mathrm{ha}^{-1}$ ). Maximum translocation of assimilates in pinching at 35 DAS has resulted in maximum number of seeds pod ${ }^{-1}$ and weight of seeds per pod which in 


\begin{tabular}{|c|c|c|c|c|c|c|c|c|}
\hline Treatments & $\begin{array}{l}\text { Seed yield } \\
\left(q \text { ha }^{-1}\right)\end{array}$ & $\begin{array}{c}\text { Straw yield } \\
\left(\mathrm{q} \mathrm{ha} \mathrm{ha}^{-1}\right)\end{array}$ & $\begin{array}{c}\text { Biological } \\
\text { yield }\left(\mathrm{q} \mathrm{ha} \mathrm{h}^{-1}\right)\end{array}$ & $\begin{array}{c}\text { Harvest } \\
\text { index (\%) }\end{array}$ & $\begin{array}{l}\text { Chlorophyll } \\
\text { (SPAD Value) }\end{array}$ & $\begin{array}{l}\text { Germina- } \\
\text { tion (\%) }\end{array}$ & $\begin{array}{c}\text { Seedling } \\
\text { vigour index }\end{array}$ & $\begin{array}{c}\text { Protein } \\
(\%)\end{array}$ \\
\hline \multicolumn{9}{|l|}{ Sowing dates } \\
\hline $25^{\text {th }}$ September & 14.00 & 43.08 & 57.10 & 24.31 & 54.79 & 91.00 & 2297.27 & 16.97 \\
\hline $10^{\text {th }}$ October & 18.55 & 44.48 & 63.03 & 29.31 & 59.43 & 97.33 & 2334.33 & 18.63 \\
\hline $25^{\text {th }}$ October & 16.02 & 44.02 & 60.04 & 26.57 & 59.39 & 93.67 & 2190.63 & 17.41 \\
\hline $9^{\text {th }}$ November & 11.68 & 41.97 & 53.66 & 21.73 & 55.33 & 73.66 & 1660.72 & 15.92 \\
\hline SEm \pm & 0.490 & 0.192 & 0.499 & 0.683 & 0.400 & 0.747 & 31.890 & 0.339 \\
\hline $\operatorname{CD}(p=0.05)$ & 1.697 & 0.665 & 1.728 & 2.365 & 1.387 & 2.585 & 110.355 & 1.176 \\
\hline \multicolumn{9}{|l|}{ Stage of pinching } \\
\hline No pinching & 13.38 & 42.60 & 55.99 & 23.76 & 56.60 & 80.00 & 1926.12 & 15.94 \\
\hline Pinching at 25 DAS & 14.73 & 43.40 & 58.13 & 25.04 & 56.99 & 91.00 & 2127.87 & 17.49 \\
\hline Pinching at 35 DAS & 17.08 & 44.16 & 61.25 & 27.63 & 58.11 & 95.75 & 2308.21 & 18.27 \\
\hline SEm \pm & 0.559 & 0.348 & 0.579 & 0.778 & 0.393 & 0.58 & 30.99 & 0.305 \\
\hline $\mathrm{CD}(p=0.05)$ & 1.678 & 1.045 & 1.737 & 2.333 & 1.178 & 1.76 & 92.93 & 0.915 \\
\hline
\end{tabular}

turn increased the seed yield. This increasing trend of number of seeds and weight of seeds per pod has resulted in maximum harvest index. Thus the maximum harvest index $(27.63 \%)$ was recorded in Pinched at 35 DAS while minimum (23.76\%) in no pinching. Similar results were also reported by Sajjan (2002) in okra, Baloch and Zubair (2010) in chick pea.

The chlorophyll content in leaves differed significantly with pinching. Among the pinching treatments the plants pinched at 35 DAS recorded maximum Chlorophyll (58.11 SPAD value) at 75 DAS. These results are attributed mainly because the pinching of plants prolongs the vegetative growth which is very well evidenced from the delayed flowering in the plants pinched at 35 DAS. As the vegetative growth was extended the photosynthetic activity was also maximum in Pinching at 35 DAS as compared to Pinching at 25 DAS and no pinching. Thus pinching improves the translocation of photosynthates from source to sink increasing the chlorophyll content in leaf tissue inturn resulted in the significant increase in crude protein content due to pinching at 35 DAS. These results may be attributed due to increased nitrogen concentration in seed which is an integral part of protein. Galactomannon differed non-significantly due to pinching. Maximum galactomannon content $(25.78 \%)$ was recorded in the plants pinched at 35 DAS, while minimum galactomannon $(25.57 \%)$ was recorded in plants without pinching. Germination (\%) and seedling vigour differed significantly due to pinching. Maximum germination (95.75\%) and seedling vigour (2308.22) was recorded in the plants pinched at 35 DAS, while minimum germination (80.00\%) and seedling vigour (1926.12) was recorded non-pinched plants. Seed quality attributes were significantly higher in pinched plants suggesting that pinching of apical bud greatly influenced the seed quality. The better performance of pinched plants was because of more number of branches, increase in photosynthetic area leading to higher photosynthetic rate, accumulation of more photosynthates resulting into better seed development which ultimately caused better seed germination and seedling vigour index. Similar increase in germination and decrease in electrical conductivity of seed leachate with apical bud pinching at 40 DAS were noticed by Sajjan et al. (2002) in okra while, increased vigour index with apical pinching was also reported by Venkatareddy et al. (1997) in okra.

\section{Conclusion}

Sowing of fenugreek on $10^{\text {th }}$ October recorded maximum growth and yield attributes while, $25^{\text {th }}$ September sown crop took maximum days for $50 \%$ flowering and maturity. Pinching at 35 DAS found to be superior in respect to all attributes except germination percentage of seeds, seedling vigour index, protein and galactomannon for 75 DAS.

\section{Refrences}

Ayub, M., Nadeem, M.A., Tanveer, A., Tahir, M., Saqib, M.T.Y., Nawaz, R., 2008. Effect of different sowing methods and times on the growth and yield of fennel (Foeniculum vulgare M.). Pakistan Journal of Botany 40(1), 259-264.

Baloch, M.S., Zubair, M., 2010. Effect of nipping on growth and yield of chickpea. Journal of Animal \& Plant Sciences 20(3), 208-210.

Castillo, A.G., Hampton, J.G., Coolbear, P., 1994. Effect of sowing date and harvest timing on seed vigour in garden pea (Pisum sativum L.). New Zealand Journal of Crop and Horticulture Sciences 22, 91-95.

Krishnaveni, V., Padmalatha, T., Padma, S.S., Prasad, A.L.N., 2014. Effect of pinching and plant growth regulators on growth and flowering in fenugreek (Trigonella foenum - 
graecum L.). Plant Archives 14(2), 901-907.

Lakshmi, J., Gowda, R., Parashivamurthy, Narayanaswamy, S., Shivanandan, V.N., 2015. Influence of pre - flowering pinching and Maleic hydrazide spray on plant growth, seed yield and quality attributes in fenugreek. Legume Research 38(3), 353-357.

Nandre, D.R., Ghadge, R.G., Rajput, B.S., 2011. Effect of sowing dates and nutrient management on growth and seed yield of fenugreek. Advances in Research Journal of Crop Improvement 2(2), 215-220.

Pansey, V.G., Sukhatme, P.V., 1985. Statistical Methods, for Agricultural Workers (4 ${ }^{\text {th }}$ Edn.). ICAR Publication, New Delhi.

Sajjan, A.S., 2002. Influence of apical pinching and fruit picking on growth and seed yield in okra. Karnataka Journal of Agricultural Sciences 15(2), 367-372.
Selim, S.M., Ebtsam, M.M.A., Tawfik, M.S.H., Abou-Sreea, A.I., 2013. Effect of sowing date, row spacing and bio-fertilizer on yield and oil quality of fennel plant (Foeniculum Vulgare, M.). Australian Journal of Basic and Applied Sciences 7(2), 882-894.

Vasudevan, S.N., Sudarshan, J.S., Kurdikeri, M.B., Dharmatti, P.R., 2008. Influence of pinching of apical bud and chemical sprays on seed yield and quality of fenugreek. Karnataka Journal of Agricultural Sciences 21(1), 26-29. Venkatareddy, D.M., Chandrashekara, B.P., Chandra Shekara, R., 1997. Effect of apical pinching and fruit thinning on yield seed quality in Okra (Abelmoschus esculentus). Seed Research 25, 41-44. 